\title{
PERCEPTION OF COLLEGE OF EDUCATION LECTURERS ABOUT TECHNICAL EDUCATION RESEARCH AND EVALUATION IN NIGERIA
}

\section{O. O. KENNEDY (PhD)}

\begin{abstract}
The study was conducted to ascertain the perception of Federal College of Education Technical lecturers towards technical education research in South-South geo-political zone of Nigeria. In pursuance of this purpose, four research questions were formulated and one hypothesis tested. The population comprised of 70 lecturers of Federal Colleges of Education (Technical) in Asaba, Umunze and Omoku. The entire population was used for the study. No sampling was done because of the fewness of the population. The design used was a survey. The instrument used was the questionnaire. On the whole 57 items were drawn using the likert scale format. The instrument was considered valid by experts with the reliability coefficient of 0.89 using Cronbach alpha. Simple percentage and t-test were used to analyse the data. The study revealed that: Government's inactive role in supporting and promoting research activities in colleges of education (technical) caused low morale of lecturers towards research; A lot of constraints such as poor attitude to research, falsification of research data, among others are the challenges of technical education research. The study recommends among others that: About 10 percent of the education tax fund should be voted to research; Government should improve its communication network.
\end{abstract}

\section{INTRODUCTHON}

Research in technical education requires space in the form of buildings, equipments, libraries and research oriented teachers.

The basic element of an effective research is to use the knowledge acquired from research to solve the practical problems of our developing society. In the same vein, research in technical education is also justified if it helps the teacher to teach more effectively and to acquire higher degrees (Adeyeri, 1989; Eyibe, 1990:a).

This paper considers the place of research in technical education in Colleges of Education, technical in Nigeria. The College of Education (Technical) is a teacher education programme that prepares N.C.E (Technical) teachers with the intellectual and professional background adequate for teaching technical and vocational subjects and to make them adaptable to any changing situation in technological development, not only in Nigeria but also, in the world at large.

\section{Research Evaluation}

Evaluation is the process of gathering and analyzing information to aid judgement of merit in decision making. It involves the assessment, appraisal, and estimation of the quality of the educational inputs, learning process and outcome for the purpose of making value judgment for quality improvement. Igwe (2004) refers to evaluation as an in-build mechanism for managing and monitoring learning.

Evaluation in technical education research is a forum for technical education researchers, teachers and students to share their views on the broad field of vocational 
technical education and the inter-rated disciplines which is documented in journals. Traditionally, a journal is defined as a print medium through which research works, informed comments and opinions of high scholastic quality may be published not only

- for the benefit of the learners and all those seeking new information, but also for policy and decision-makers (Dosunmu, 1989). Therefore, every article submitted to such a journal for publication must be presented to a knowledgeable reader or assessor in the field for comment.

\section{Statement of the Problem}

Research in every endeavour of life is a stepping stone to national development. In developed countries of the world, research is highly regarded and funded. The reason being that a nation's development depends on the effectiveness of her research efforts. In advanced countries, research is monitored and findings are often implemented. Research and teaching are the primary functions of various departments in the tertiary institutions of the world. For these functions to be performed effectively according to Odu (2007), human and material resources should be in place to make up a good atmosphere for the teaching and research. On the side of the government, research and evaluation are irrelevant and are therefore can merely serve for academic exercise (Adeyeri, 1989, Eyibe , 1990:a).

The problem this study intends to tackle is to find out whether poor attitude of government towards research is the only challenges faced by Federal College of Education (Technical) lecturers in conducting and evaluating research in technical education or are there any other hindrances encountered by the lecturers? Specifically, this study sought answers to the following research questions.

1. To what extent has government contributed to the low morale of lecturers in carrying out their research activities?

2. What is the perception of Federal College of Education (Technical) lecturers towards constraints encountered in conducting their research activities?

3. To what extent are lecturers of Federal College of Education (Technical) competent in carrying their researches and evaluation?

4. How adequate are the criteria for evaluation of articles for academic journal in college of education technical?

\section{Hypothesis}

Ho: The responses of male and female lecturers of Federal Colleges of Education (Technical) about their constraints in carrying out their research activities and evaluation will not differ significantly.

\section{Methodology}

The study utilized the ex-post factor research design. The reason for using this design was because the study was based on an existing facts. The population comprised of 70 lecturers in the school of Technical Education from Federal Colleges of Education (Technical) in the South-South zone of Nigeria. These colleges include Federal Colleges of Education (Technical), Asaba, Delta State; Federal College of Education (Technical) Omoku, Rivers State and Federal College of Education (Technical), 
Umunze, Anambra State. The entire population was surveyed. Because of the fewness of the population all the 70 technical education lecturers were used for the study.

A 57-item questionnaire which covered extent of government contribution to low morale of lecturers in research activities with 10 items; constraints of lecturers in Conducting and Evaluating research Activities with 14 items; Competency of lecturers in carrying out research activities with 24 items; criteria for evaluating articles for academic journal with 9 items. The instrument was validated by three lecturers from the department of technical and business education, Delta Sate University Abraka. They scrutinized the questionnaire. Their comments were assembled and based on their corrections, three items were dropped and finally leaving the questionnaire with 57 items. A reliability coefficient of 0.89 was obtained using Cronbach alpha. A total of 70 copies of the questionnaire were administered. The respondents were requested to complete the questionnaire and returned same to the investigator.

All copies of the questionnaire were duly completed and returned for analysis. Data collected were analyzed by means of frequency count, percentage and t-test.

\section{Results}

The results of the study are presented in table 1-5 based on the research questions and hypothesis.

\section{Research Question 1}

To what extent has government contributed to the low morale of lecturers in carrying out their research activities?

Table 1: Extent of Government's Contribution to the Low Morale of Lecturers in Research Activities

\begin{tabular}{|c|c|c|c|c|c|}
\hline $\mathbf{S} / \mathbf{N}$ & Items & $\begin{array}{l}\text { Number } \\
\text { Agreeing }\end{array}$ & $\%$ & $\begin{array}{l}\text { Number } \\
\text { Disagreeing }\end{array}$ & $\%$ \\
\hline 1. & Poor Finding & 62 & 89 & 8 & 11 \\
\hline 2. & $\begin{array}{l}\text { Poor n eans of co-ordinating } \\
\text { and disseminating research } \\
\text { findings }\end{array}$ & 66 & 94 & 4 & 6 \\
\hline 3. & $\begin{array}{l}\text { Inadequate supply of suitable } \\
\text { research personnel }\end{array}$ & 53 & 76 & 17 & 24 \\
\hline 4. & Poor enabling environment & 51 & 73 & 19 & 27 \\
\hline 5. & Inadequate laboratories & 55. & 79 & 15 & 21 \\
\hline 6. & Inadequate studios & 50 & 71 & 20 & 29 \\
\hline 7. & Inadequate library space & 56 & 80 & 14 & 20 \\
\hline 8. & Dearth in hand tools & 54 & 77 & 16 & 23 \\
\hline 9. & Dearth in machine & 55 & 79 & 15 & 21 \\
\hline 10. & $\begin{array}{l}\text { Scarcity of training materials } \\
\text { for applied research }\end{array}$ & 50 & 71 & 20 & 29 \\
\hline
\end{tabular}


Items in Table 1 sought to find out the extent of government's contribution to the low morale of lecturers in carrying out their research activities. The average percent by respondents in favour of government's contribution to low morale of lecturers to research is $79 \%$ while $21 \%$ of the cases show the unfavourable disposition of the respondents about government's contribution to the low morale of lecturers towards their research activities.

\section{Research Question 2}

What is the perception of Federal College of Education (Technical) lecturers towards constraints they encountered in conducting their research activities?

Table 2: $\quad$ Perception of Lecturers towards Constraints in Conducting Their Research Activities

\begin{tabular}{|c|c|c|c|c|c|}
\hline $\mathbf{S} / \mathbf{N}$ & Items & $\begin{array}{l}\text { Number } \\
\text { Agreeing }\end{array}$ & $\%$ & $\begin{array}{l}\text { Number } \\
\text { Disagreeing }\end{array}$ & $\%$ \\
\hline 1. & Poor research attitude & 57 & 81 & 13 & 19 \\
\hline 2. & $\begin{array}{l}\text { Unwillingness of the respondents to } \\
\text { pass research information to the } \\
\text { researchers }\end{array}$ & 52 & 74 & 18 & 26 \\
\hline 3. & $\begin{array}{l}\text { Indolence in undertaking research } \\
\text { activities }\end{array}$ & 49 & 70 & 21 & 30 \\
\hline 4. & Falsification of research data & 53 & 76 & 17 & 24 \\
\hline 5. & Plagiarism & 59 & 84 & 11 & 16 \\
\hline 6. & Use of obsolete literature & 55 & 79 & 15 & 21 \\
\hline 7. & $\begin{array}{l}\text { Inaccurate reporting of research } \\
\text { results }\end{array}$ & 58 & 83 & 12 & 17 \\
\hline 8. & Inadequate books for consultation & 41 & 59 & 29 & 41. \\
\hline 9. & Scarcity of relevant journals & 53 & 76 & 17 & 24 \\
\hline 10. & Inadequate periodicals & 42 & 60 & 28 & 40 \\
\hline 11. & Poor library facilities & 62 & 89 & 8 & 11 \\
\hline 12. & $\begin{array}{l}\text { Lecturers undertake research not } \\
\text { because of their contribution to } \\
\text { knowledge but because of } \\
\text { promotion }\end{array}$ & 56 & 80 & 14 & 20 \\
\hline 13. & $\begin{array}{l}\text { Most information from internet does } \\
\text { not suit our local situation }\end{array}$ & 55 & 79 & 15 & 21 \\
\hline 14. & $\begin{array}{l}\text { Poor communication network as } \\
\text { found in telephone, internet, email } \\
\text { or facsimile }\end{array}$ & 50 & 71 & 20 & 29 \\
\hline & Average Percent $76(+) 24(-)$ & & & & \\
\hline
\end{tabular}

Items considered in Table 2 were used to verify the perception of Federal College of Education (Technical) lecturers towards their constraints in research activities.

The average percentage level of their constraints is $76 \%$ while $24 \%$ of the respondents claimed that there were no such constraints in conducting their researches. 


\section{Research Question 3}

To what extent are lecturers of Federal College of Education (Technical) competent in carrying their researches and evaluation?

Table 3: Competency of Lecturers in carrying out Researches

\begin{tabular}{|c|c|c|c|c|c|}
\hline $\mathbf{S} / \mathbf{N}$ & Items & $\begin{array}{l}\text { Number } \\
\text { Agreeing }\end{array}$ & $\%$ & $\begin{array}{l}\text { Number } \\
\text { Disagreeing }\end{array}$ & $\%$ \\
\hline 1. & $\begin{array}{l}\text { Research title of lecturers in Federal } \\
\text { Colleges of Education (Technical) is } \\
\text { suitable and is addressing a neglected } \\
\text { issue }\end{array}$ & 61 & 87 & 9 & 13 \\
\hline 2. & $\begin{array}{l}\text { Title of research paper is properly } \\
\text { addressed and likely to fill a gap in } \\
\text { current knowledge or practice }\end{array}$ & 58 & 83 & 12 & 17 \\
\hline 3. & Problem of study is clearly stated. & 56 & 80 & 14 & 20 \\
\hline 4. & $\begin{array}{l}\text { Literature review is relevant to the } \\
\text { study }\end{array}$ & 52 & 74 & 18 & 26 \\
\hline 5. & Literature review is adequate & 50 & 71 & 20 & 29 \\
\hline 6. & Literature review is up-to-date & 45 & 64 & 25 & 36 \\
\hline 7. & $\begin{array}{l}\text { Authors demonstrate an adequate } \\
\text { understanding of the current literature } \\
\text { in the field }\end{array}$ & 60 & 86 & 10 & 14 \\
\hline 8. & $\begin{array}{l}\text { The literature review throw up a need } \\
\text { for the study }\end{array}$ & 58 & 83 & 12 & 17 \\
\hline 9. & $\begin{array}{l}\text { The paper employ theory in a } \\
\text { meaningful way }\end{array}$ & 42 & 60 & 28 & 40 \\
\hline 10. & $\begin{array}{l}\text { The objectives of the study are clearly } \\
\text { stated }\end{array}$ & 50 & 71 & 20 & 29 \\
\hline 11. & $\begin{array}{l}\text { The objectives of the study are } \\
\text { adequate vis-à-vis the title }\end{array}$ & 48 & 69 & 22 & 31 \\
\hline 12. & $\begin{array}{l}\text { Opinion papers provide a critical } \\
\text { analysis of existing points of view. }\end{array}$ & 63 & 90 & 7 & 10 \\
\hline 13. & $\begin{array}{l}\text { The pi per provide a new } \\
\text { understan'ing of the problem of study }\end{array}$ & 47 & 67 & 23 & 33 \\
\hline 14. & $\begin{array}{l}\text { In empirical papers, method of data } \\
\text { collection (test, questionnaire, } \\
\text { interview, observation, document etc) } \\
\text { is adequate }\end{array}$ & 56 & 80 & 14 & 20 \\
\hline 15. & Method of data analysis is appropriate & 40 & 57 & 30 & 43 \\
\hline 16. & Tables are properly presented & 60 & 86 & 10 & 14 \\
\hline 17. & $\begin{array}{l}\text { Statistical values obtained are } \\
\text { correctly interpreted }\end{array}$ & 57 & 81 & 13 & 19 \\
\hline 18. & $\begin{array}{l}\text { Results/findings reflect all the } \\
\text { objectives }\end{array}$ & 45 & 64 & 25 & 36 \\
\hline 19. & $\begin{array}{l}\text { Results/findings are adequately } \\
\text { explained and situated in previous } \\
\text { findings }\end{array}$ & 41 & 59 & 29 & 41 \\
\hline 20. & $\begin{array}{l}\text { Conclusions of the study are clearly } \\
\text { stated. }\end{array}$ & 54 & 77 & 16 & 23 \\
\hline
\end{tabular}


21. The conclusions are adequately tie 59 together to the results of the study

22. All the cited authors in the text are 61 listed in the references.

23. The references conform to the APA 15 format.

24. The standard of writing, including 43 spelling and grammar is satisfactory.

$\begin{array}{lll}84 & 11 & 16 \\ 87 & 9 & 13 \\ 21 & 55 & 79 \\ 61 & 27 & 39\end{array}$

16 13

79

39 Average percent $73(+) 27(-)$

Table 3 shows the level of competencies exhibited by Federal College of education (Technical) lecturers towards their research activities and evaluation. The average response in agreement that the lecturers' posses enough competencies in carrying out their research is $73 \%$ while $27 \%$ disagreed with these responses.

\section{Research Question 4}

How adequate are the criteria for evaluation of articles for academic journal in college of education technical?

Table 4: Criteria for Evaluating Articles for Academic Journals of Technical Education

\begin{tabular}{llllll}
\hline S/N & Items & $\begin{array}{l}\text { Number } \\
\text { Agreeing }\end{array}$ & $\begin{array}{l}\text { Number } \\
\text { Disagreeing }\end{array}$ & $\%$ \\
\hline 1. & $\begin{array}{l}\text { Original contribution relevant } \\
\text { vocational technical education }\end{array}$ & 66 & 94 & 4 & 6 \\
2. & Evidence of Scholarship & 60 & 86 & 10 & 14 \\
3. & Content of subject matter & 68 & 97 & 2 & 3 \\
4. & Soundness of treatment & 63 & 90 & 7 & 10 \\
5. & Clarity of Presentation & 53 & 76 & 17 & 24 \\
6. & Clear research methods for empirical & 59 & 84 & 11 & 16 \\
7. & research & 49 & 70 & 21 & 30 \\
8. & $\begin{array}{l}\text { Results and discussion for empirical } \\
\text { research }\end{array}$ & 64 & 91 & 6 & 9 \\
9. & Conclusion and recommendation & 54 & 77 & 16 & 23 \\
\hline
\end{tabular}

Table 4 indicates the criteria used by Federal Colleges of Education (Technical) Lecturers in evaluating articles for their technical education journal. The average response in favour of the criteria is $85 \%$ while the response against the criteria is $15 \%$. $\mathrm{H}_{\mathrm{ol}}$ : The responses of male and female lecturers of federal college of education (Technical) about their constraints in carrying out their research activities and evaluation will not differ significantly. 
Table 5: $\quad$ T-Test Comparison of Male and Female Lecturers of Colleges of Education (Technical) about Constraints to Technical Education Research and Evaluation

\begin{tabular}{|c|c|c|c|c|c|c|c|c|}
\hline $\mathbf{S} / \mathbf{N}$ & Items & $\frac{\text { Group }}{X_{1}}$ & $\begin{array}{l}(\mathrm{SD} \\
\mathbf{1}^{2}\end{array}$ & $\frac{\text { Group }}{X_{2}}$ & $\left(\mathrm{SD}_{2}\right)^{2}$ & t-cal & t-crit & Decision \\
\hline 1. & Poor research attitude & 3.96 & 1.18 & 3.99 & 1.17 & 0.17 & 2.000 & NS \\
\hline 2. & $\begin{array}{l}\text { Unwillingness of respondents to } \\
\text { pass research information to the } \\
\text { researchers. }\end{array}$ & 4.18 & 1.05 & 4.20 & 1.03 & 0.13 & 2.000 & NS \\
\hline 3. & $\begin{array}{l}\text { Indolence in undertaking research } \\
\text { activities }\end{array}$ & 4.36 & 0.84 & 4.38 & 0.81 & 0.08 & 2.000 & NS \\
\hline 4. & Falsification of Research Data & 4.40 & 0.85 & 4.41 & 0.83 & 0.08 & 2.000 & NS \\
\hline 5. & Plagiarism & 3.78 & 1.32 & 3.79 & 1.31 & 0.05 & 2.000 & NS \\
\hline 6. & Use of obsolete literature & 3.80 & 1.30 & 3.79 & 1.29 & 0.09 & 2.000 & NS \\
\hline 7. & Error in reporting research results & 4.02 & 1.16 & 4.05 & 1.11 & 0.17 & 2.000 & NS \\
\hline 8. & Inadequate books for consultation & 3.74 & 1.35 & 3.72 & 1.36 & 0.17 & 2.000 & NS \\
\hline 9. & Scarcity of relevant journal & 3.73 & 1.26 & 3.71 & 1.25 & 0.02 & 2.000 & NS \\
\hline 10. & Inadequate periodicals & 3.75 & 1.29 & 3.74 & 1.30 & 0.09 & 2.000 & NS \\
\hline 11. & Poor library facilities & 4.30 & 1.27 & 3.78 & 1.27 & 0.18 & 2.000 & NS \\
\hline 12. & Poor funding & 4.31 & 0.96 & 4.18 & 1.07 & 1.46 & 2.000 & NS \\
\hline 13. & $\begin{array}{l}\text { Lecturers undertake research not } \\
\text { because of their contribution to } \\
\text { knowledge but because of } \\
\text { promotion }\end{array}$ & 4.35 & 1.01 & 4.47 & 0.99 & 0.23 & 2.000 & NS \\
\hline 14. & $\begin{array}{l}\text { Most information from internet does } \\
\text { not suit our local situation }\end{array}$ & 3.79 & 1.33 & 3.87 & 1.25 & 1.24 & 2.000 & NS \\
\hline 15. & $\begin{array}{l}\text { Poor computer usage and } \\
\text { application }\end{array}$ & 3.64 & 1.41 & 3.63 & 1.42 & 0.08 & 2.000 & NS \\
\hline
\end{tabular}

$\mathrm{N}_{1}=42 ; \mathrm{N}_{2}=28$

$\mathrm{Df}=68$

Group $1\left(\mathrm{~N}_{1}\right)$ - Male lecturers of Federal College of Education (Technical)

Group $2\left(\mathrm{~N}_{2}\right)$ - Female lecturers of Federal College of Education (Technical)

$\mathrm{S}$ - Significant

NS - Not Significant

Analysis of the opinions of the two groups of respondents (Male and Female lecturers) provided various computed t-value compared with the $t$-table value. The table - value at 41 and 27 degree of freedom (df) given 0.05 level of significance is 2.000. However, the calculated $t$-values of all items are less than the t-table value of 2.000. Therefore the Null Hypothesis is accepted. This shows that there is no significant difference in the opinion of male and female lecturers of Federal Colleges of Education Technical on their constraints to technical education research.

\section{Findings}

This research has revealed the following findings:

1. Government's inactive role in supporting and promoting research activities in colleges of education technical has caused the low morale of lecturers in carrying out their research activities. These hindrances posed by the 
government are poor funding, poor means of co-ordinating and disseminating research findings, inadequate supply of suitable research personnel, and poor enabling environment such as lack of workshops, laboratories, studios and libraries.

2. A lot of constraints such as poor attitude to research by lecturers, falsification of research data, plagiarism, error in reporting research results, use of obsolete literature, inadequate books, journals, periodicals, unwillingness of the respondents in giving information to the researchers are some of the challenges contending with the lecturers in carrying out their research in technical education, poor communication network as found in telephone, internet, email or facsimile.

3. Lecturers of federal colleges of education (technical) posses enough competencies in carrying out their research work.

4. The criteria for evaluating articles for academic journals in colleges of education technical are adequate.

\section{Discussion}

This study was conducted to determine the perception of college of education technical lecturers about technical education research and evaluation in Nigeria. Results obtained reveal that government's nonchalant attitude have contributed immensely to the low morale of lecturers in carrying out their research activities. Lack of funding of technical education research, poor means of coordinating and disseminating research findings, inadequate supply and motivation of existing research personnel, lip-service of the governments: federal, state and the local government councils and their agencies, poor enabling environment, lack of research facilities and equipment are some of the factors that cause lecturers' morale to be low in carrying out research work. The findings agreed extensively with the earlier reports of Nduka and Iheoma (1983); Ibe-Bassey (1988) and Nworgu (1991), which highlighted some of the obstacles to research personnel in the third world nations including Nigeria. According to these school of thoughts, the identified constraints which however, focused on human and material resources distribution, human attitude and negligence required careful analysis and total amelioration in order to ensure the place of technical education research.

Garba (2000) observed that unwillingness of the industrial organisations to commercialize research findings has been a problem to many breakthroughs.

From the findings of the study, poor means of coordinating and disseminating research results is a bottle-neck in research development. Government does not use and implement research findings, if it does, then the number is too infinitesimal. A nation that does not heed and allow for the development of research result is heading for a doom. Such nations cannot invest the bountiful fruits of research. It is indeed through the commercialization and relevant application of research results that nation could be technologically and economically buoyant (Mahea, 1970; Jacob, 1987; Eyibe, 1989).

Furthermore, constraints such as poor attitude to research by lecturers, falsification of research data, plagiarism, error in reporting research results, lack of research facilities and equipment, poor communication network as found in telephone, internet, email or 
facsimile are some of the variables that hinder research activities in colleges of education (Technical). This assertion has confirmed (Nworgu, 1991) why research in Nigeria has not progressed beyond what must be described as the foundation level.

Lack of enabling environment, from the finding of this study also contributes to poor research activities in Nigeria. Research and teaching are the primary functions of various departments in the tertiary institutions of the world. For these functions to be performed effectively human and material resources should be in place to make up a good atmosphere for the teaching and research (Hassan, 2003). It is unfortunate for Nigeria, a country that has been crying for technological growth, technological emancipation and technological breakthrough has little to show up in terms of enabling environment. No matter how good the teaching staffs are, they may not deliver the goods without adequate materials. Few technical writers exist in Nigeria and it is not enough to rely on our local authors and publishers for all library needs. The availability of facilities, like workshops, studios laboratories and libraries will no doubt create an enabling environment for more researches in technical education (Onyeukwu, 1989; Imarhiagbe, 1992). But the reverse is the case in our tertiary institutions.

From the findings of the study in Table 3, it was discovered that lecturers of Federal College of Education Technical possess enough competencies to carry out with their research work and evaluation. Research competence according to Kajang (2006), is the process of arriving at dependable answers to problems through a planned and systematic approach, which is dependent on successful integration of theory into practical by teachers/lecturers. Technical education lecturers in Federal Colleges of Education are well trained and research-oriented. They are academically and professionally skills to inform, motivate, challenge, train, and stimulate technical education research. According to Modibbo, (1989); Ivowi (1990) and Eyibe (1990:b) College of Education lecturers need to promote in their students enterprise, technical ability, intellectual curiosity, innovation, productivity in technical education research.

The finding of the study in Table 4 indicates that all the criteria for evaluating articles for academic journals of Colleges of Education (Technical) were adequate. An academic paper should investigate a problem situation, offer solutions to such problems and crusade ideas within the article to qualify for selection (Ross, 1972).

\section{Conclusion}

From the foregoing, it is very clear that development of research activities in Nigeria is faced with a number of hurdles. It is therefore no doubt that with serious determination, sound planning, provision of better facilities and funding of research in tertiary institutions particularly in Federal Colleges of Education (Technical), fruitful researches will be carried out and proper application of the findings will transform Nigeria from traditional to a technological society in future.

\section{Recommendations}

On the basis of the findings and conclusion, the following recommendations are made: 
Government should assist technical education research in Federal Colleges of education (Technical) in the following ways:

1. Provide sufficient fund to support their research activities. About 10 percent of the education tax fund should be voted for research in technical education.

2. Improve its communication network such as the telephone, internet, email or the facsimile services such that an average researcher can carryout his projects at a minimal and affordable rate.

3. Procure books and other library materials for the institutions.

4. Provide enabling environment for research activities.

\section{References}

Adeyeri, J. B. (1989). Evaluation of Research Reports in Polytechnics: Criteria, Methods and Application. A Paper Presented at a National Seminar on Applied Research and Technology Adaptation in Polytechnics held at NBTE Conference Room. Kaduna on September 26-29.

Dosunmu, T. (1989). Criteria for Selecting Papers for Academic Journals: A Case Study of the Nigerian Journal of Technical Education. A Paper Presented at a National Seminar on Applied Research and Technology Adaptation in the Polytechnics held at NBTE Conference Room, Kaduna on September 26-29.

Eyibe, S.C. (1989). Economic Relevance of Science and Technology Education in Developing Countries. $5^{\text {th }}$ International Symposium on World Trends in Science and Technology Education. Manila, Philippines, December 11-21.

Eyibe, S. C. (1990a). Effective Teaching as a Research Activity. In Journal of Technical Education Review, 2 (2): 3-12.

Eyibe, S.C. (1990:b). Research in Technical Education as an Anchor. In Journal of Technical Education Review. 2 (2): 1-2

Garba, D. (2000). Research and Development (R \& D) - Activities in Nigeria. Problems and Prospects Paper Presented at the Second Annual Conference of League of Researcher in Nigeria, Bauchi, 2000.

Hassan, B. (2003). Improvement of Research Activities for Technological Growth in Nigeria Through Private Sector Participation, Enabling Environment and Adequate Facilities. Nigerian Journal of Research and Production. 2 (1): 108-115.

Ibe-Bassey, G.S. (1998). How Nigerian Teachers Select Instructional Materials. British Journal of Educational Technology, 19 (1): 17-21.

Igwe, S.O. (2004). Quality and Evaluation of Teaching and Learning in Nigeria Education in B.A. Eheazu and U.M.O Ivowi (EDS) Nigeria Academy of Education Proceeding.

Imarhiagbe, K.O. (1992). Vocational Educational Programmes in Nigeria. Issues and Challenges. Journal of Technical Teacher Education, 1 (1): 45.

Ivowi, U.M.O. (1990). Appraisal of Research on the National Policy on Education. Ehiametalor, E. Izuagie, M. and Olaitan, S.O. (eds): Implementation of the National Policy on Education. Benin: Ilupeju Press.

Jacob, E. (1987). Qualitative Research Traditions. A Review of Educational Research. 17 (1): 14-20.

Kajang, Y. G. (2006). Research Competence and Usage among Professional Academic Staff of Sciences F.C.E. Pankshin, Plateau State. Nigerian Journal of Science and Educational Research. 1 (1): 40-42.

Mahea, N. (1970). Main Trends of Research Paris. UNESCO. 
Modibbo, G. (1989). Increased Awareness in the Conduct of Research in Technical Education. Opening Address of the Rector, Federal Polytechnic, Mubi at a Seminar on "Research Awareness" held at the Polytechnic, November $15^{\text {th }}-17^{\text {th }}$.

Nduka, O. A. and Iheoma, E. O. (1983). New Perspectives of Moral Education. Ibadan: Evans (Nig) Publishers.

Odu, K.O. (2007). Improving the quality of technology education in Nigerian secondary schools. African Journal of Education and Developmental Studies (AJEDS). 3 (1): 45-51.

Nworgu, B.G. (1991): Educational Research: Basic Issues and Methodology. Ibadan Nigeria: Wisdom Publishers Limited.

Onyeukwu, F.D.N. (1989): Technological Growth and Private Sector Co-operation. A Paper Presented at the A.B.G./N.P. and department of E/E Forum, Kaduna Polytechnic.

Osuala E.C. (1987). Introduction to Research Methodology ( $2^{\text {nd }}$ edition). Onitsha: Africana-Fep Publishers Limited

Ross, A. (1972): Quoted by Dosunmu (1989): Criteria for Selecting Papers for Academic Journals. Op. Cit. 